Erratum de:

\title{
Physiopathologie de la mémoire autobiographique dans le vieillissement : distinction épisodique/sémantique, données cliniques et études en neuroimagerie
}

P. Piolino, P. Martinelli, A. Viard, M. Noulhiane, F. Eustache, et B. Desgranges

Biologie Aujourd'hui 204 (2010) 159-179

Nous prions nos lecteurs de nous excuser pour des erreurs qui se sont glissées dans la figure 8 de cet article.

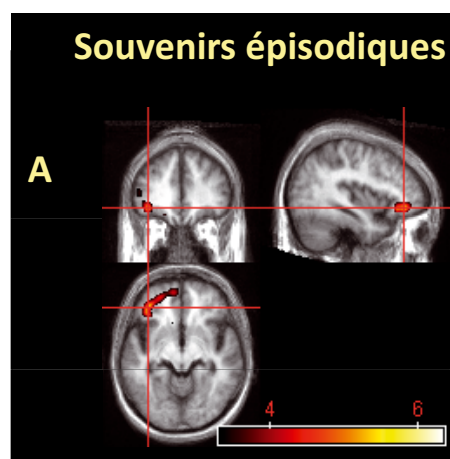

Régions frontales

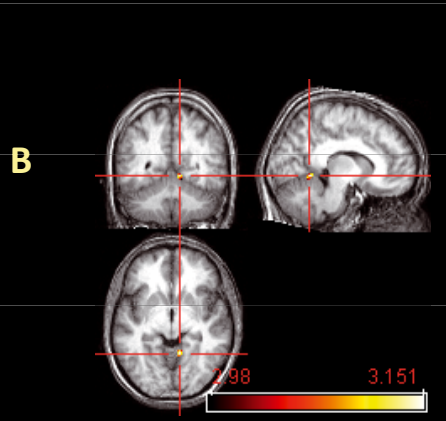

Régions hippocampiques

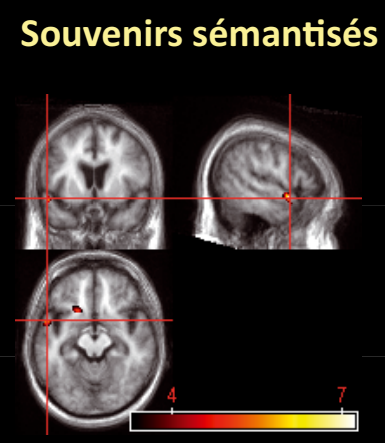

Régions temporales

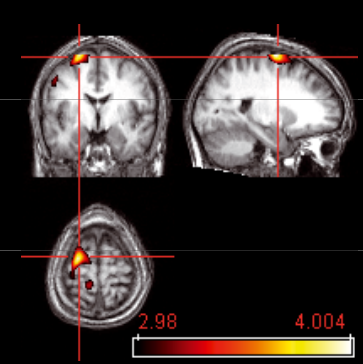

Régions frontales

Fig. 8. Corrélations entre des mesures métaboliques du glucose au repos (TEP) et des scores de souvenirs autobiographiques épisodiques ou sémantisés chez des patients atteints de démence fronto-temporale (A) et des patients Alzheimer (B). 